\title{
Powertrain and Thermal System Simulation Models of a High Performance Electric Road Vehicle
}

\author{
Massimo Stellato $^{1} \quad$ Luca Bergianti $^{2} \quad$ John Batteh $^{3}$ \\ ${ }^{1}$ Dallara Engineering, Italy m.stellatoddallara.it \\ ${ }^{2}$ Dallara Engineering, Italy 1 . bergianti da dallara. it \\ ${ }^{3}$ Modelon Inc., Ann Arbor, Michigan USA john. batteh@modelon. com
}

\begin{abstract}
Performance and range optimization of electric vehicles are challenging targets in the design of contemporary automobiles. This paper illustrates that the thermal system and the development of the related control logic are key factors in achieving these targets. Both subjects benefit from the support of modeling and simulation. The paper describes our approach applied to a real case study.

The activity is the result of a cooperation between Dallara, responsible for the case study, and Modelon, developers of the libraries used to build the simulation model.
\end{abstract}

Keywords: electric vehicle, thermal system, control logic, powertrain, battery, cooling, range, derating.

\section{Introduction}

The goal is to evaluate the potential of the simulation models to define the thermal system architecture of an electric vehicle. This approach should allow the maximum degree of freedom for the control logic to be optimized later in the project, in order to optimize both vehicle range and performance.

Thanks to new technologies in the automotive field in general and for electric vehicles, a multi-physics approach to analyze the interactions between complex subsystems becomes necessary to evaluate the vehicle performance (Bouvy et al, 2012). This need has led to the construction of a multi-physics model developed in the Modelica environment with components taken from four different application libraries: "Vehicle Dynamics", "Liquid Cooling", "Vapor Cycle" and "Heat Exchanger" (Modelon, 2016). The models are developed using Dymola (Dassault Systèmes, 2016).

\section{Case Study Description}

The activity reported in this paper supports the design of the thermal system of a real case high performance Sedan class electric vehicle which features three inboard motors (one at the front and two at the rear).
The thermal system architecture, the components and all the car data in this analysis reflect the real case.

\section{Model Description}

Figure 1 shows the top level of the "Systems Model", comprising of the following sub-models using the libraries noted:

- Driver

- Powertrain (Vehicle Dynamics Library)

- Brakes (Vehicle Dynamics Library)

- Thermal System (Liquid Cooling, Vapor Cycle and Heat Exchanger Libraries)

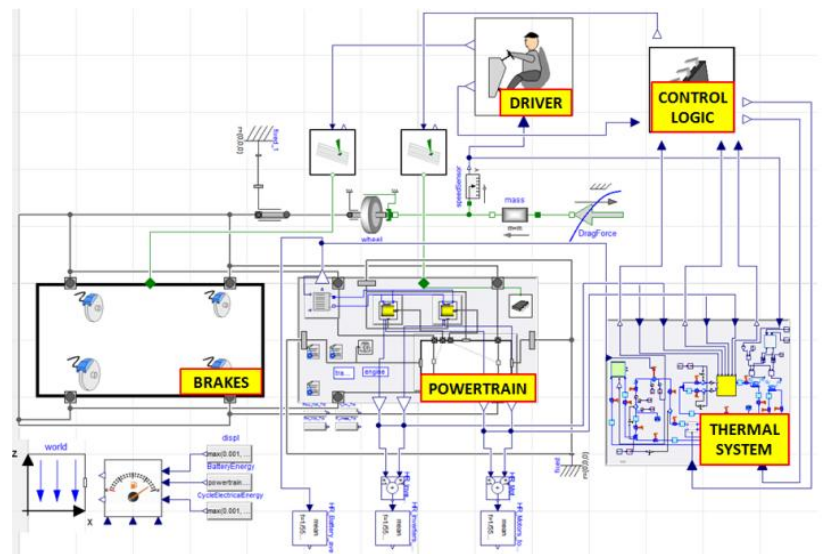

Figure 1. Systems model top view

The aim of the Systems Model is to match the reference speed profile (input) while considering the thermal limits of battery and powertrain together with the longitudinal vehicle performance (speed and acceleration) in order to calculate the range.

Figure 2 shows the main input and output of the model.

\begin{tabular}{|c|c|}
\hline $\begin{array}{l}\text { MODEL INPUT } \\
\text { - CYCLE SPEED PROFILE } \\
\text { - VEHICLE DATA } \\
\text { - RADIATORS AND FAN DATA } \\
\text { - WATER VOLUMES } \\
\text { - PUMPS CHARACTERISTIC }\end{array}$ & $\begin{array}{l}\text { MODEL OUTPUT } \\
\text { - VEHICLE SPEED PROFILE } \\
\text { - HEAT REJECTIONS } \\
\text { - RANGE } \\
\text { - COOLANT FLOW RATE } \\
\text { - COOLANT TEMPERATURES }\end{array}$ \\
\hline
\end{tabular}

Figure 2. Model input and output 
It's also possible to develop different driving cycles to represent typical real driving styles in order to evaluate their effect on the range.

The Systems Model can be interfaced with the multi-body vehicle model for vehicle dynamics analysis (Figure 3).

This approach allows both the refined analysis of the vehicle performance and the study of the cooling system at the same time.

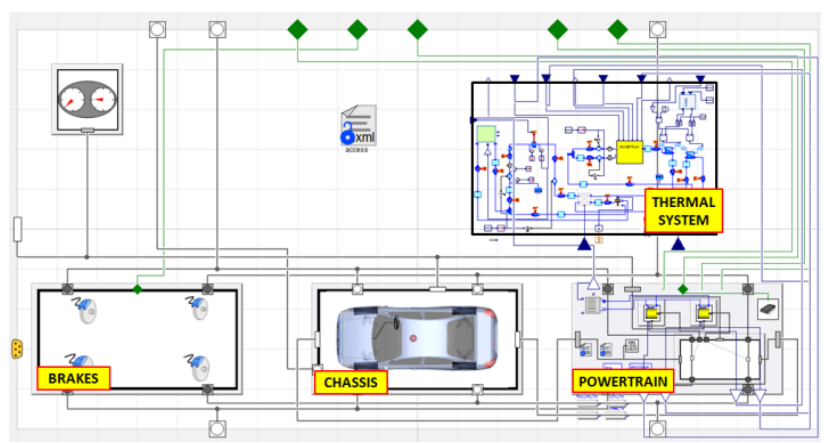

Figure 3. Full vehicle multibody model

\subsection{Driver Model}

The driver model, (see Figure 4), tries to match the speed profile (input) by varying the accelerator and brake pedal positions, which are respectively connected to the powertrain and brake models. If the coolant temperatures reach the limits, the control logic applies a progressive power derating as needed.

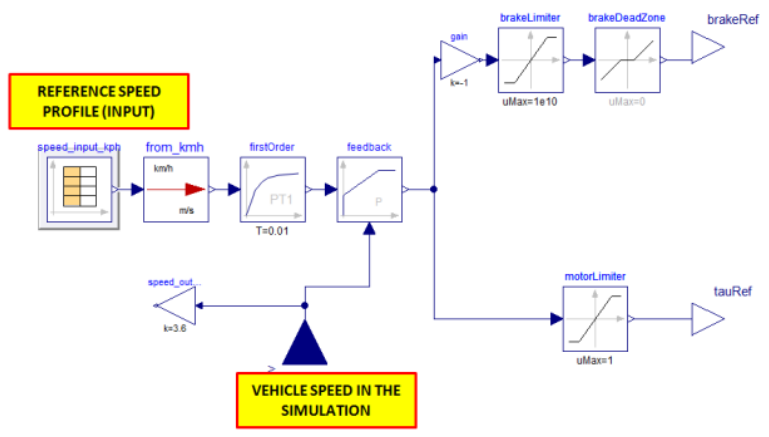

Figure 4. Driver sub-model

\subsection{Powertrain Model}

The powertrain model, illustrated in Figure 5, is composed by the following elements:

- Battery

- 3x Motors

- Driveline



Figure 5. Powertrain sub-model

The battery model has both electric and thermal features with variable internal resistance and open circuit voltage as function of state of charge and cell temperature. The cell heat capacity is modeled with a lumped thermal element storing heat. The physical interaction between the cell and the coolant is modeled with a lumped thermal element transporting heat (Figure 6).

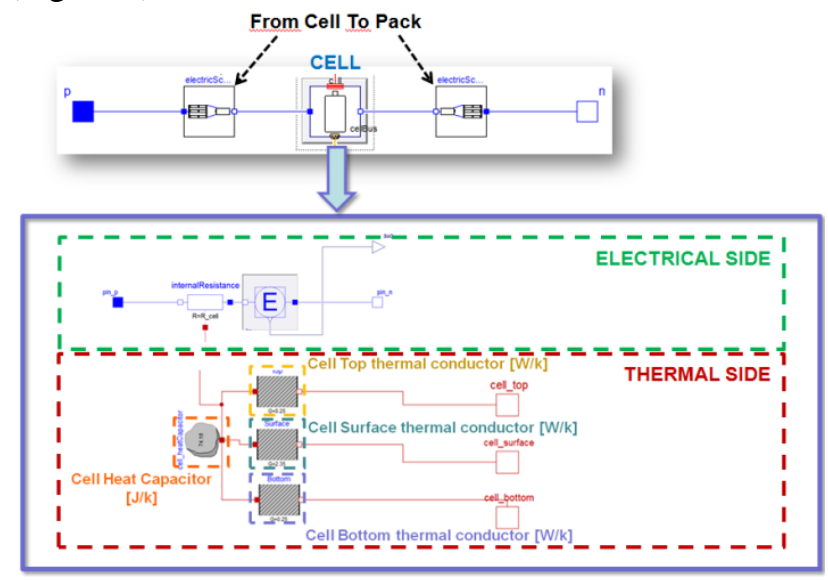

Figure 6. Battery sub-model

The model provides interfaces to the thermal system at the cell bottom, cell top or cell surface, as shown in Figure 7.



Figure 7. Cell temperature in the case of the thermal system linked to cell surface vs cell bottom

This approach looks at the irreversible heat generation due to the ohmic thermal loss caused by the battery's internal resistance, in the real case there's 
also the effect of the reversible heat due to the chemical reactions in the battery electrodes (Schmitke et al, 2015).

A finite volume and finite element method would not represent a preferable alternative for system simulations as they slow down the simulation (Krüger et al, 2012) and still does not consider the effect of the reversible heat due to chemical reactions.

The battery energy consumption is used to predict the range via the state of charge calculated by integrating the generated current over time.

The motors are characterized in terms of both peak and continuous power curves, which depend on the available voltage at the inverter inlet. This voltage depends on the generated current, open circuit voltage and internal resistance of the battery. The motor and inverter efficiencies vary with torque and rpm. The model includes both winding and stator core temperatures. The winding is not interfaced with the thermal system. The equation describing the relationships between winding temperature and peak power is provided by the motor supplier. When the winding temperature reaches the limit value, the motor available power switches gradually from peak to continuous (Figure 8). The stator core is interfaced with the thermal system through coolant ducts (Figure 9); when the coolant temperature at the stator outlet reaches its limit, the control logic applies the power derating, as described later in the paper.

The stator core modeling consists of a thermal capacitance and a thermal conductance between stator and coolant which reflect the real geometry and material property.

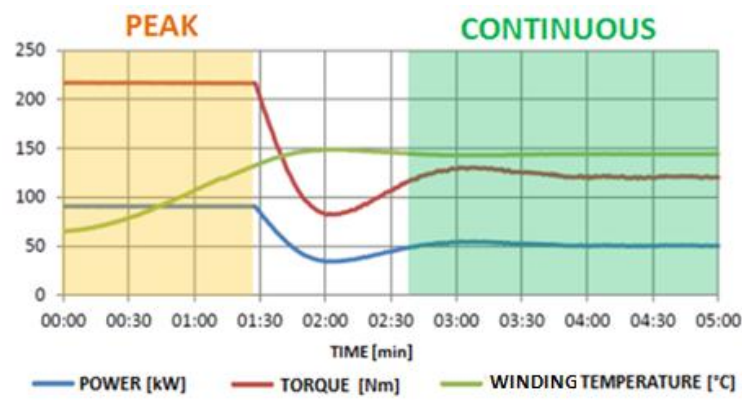

Figure 8. Winding temperature as function of peak and continuous power in a typical electric motor for automotive applications

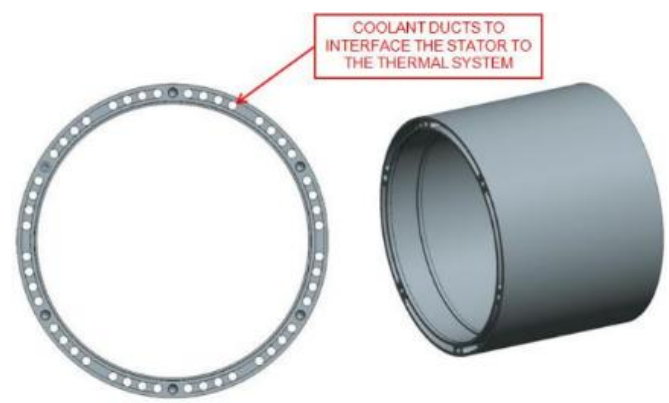

Figure 9. Stator of the electric motor
The energy recovery under braking is also considered: the motors assist the mechanical brakes by providing a torque of up to $10 \%$ that available in normal driving conditions; the energy recovery under braking affects both range and heat rejection.

An ABS / traction control model is included to avoid front and rear wheel spin during acceleration and braking.

\subsection{Thermal System Model}

The thermal system is the most innovative block of the systems model; its aim is to cool the battery and the powertrain as needed.

All the thermal components considered in the model are calibrated to match the behavior of the actual components. For example the radiator characteristic (Figure 10) has been provided by the supplier and validated by Dallara with experimental tests in the cooling rig (Figure 11).

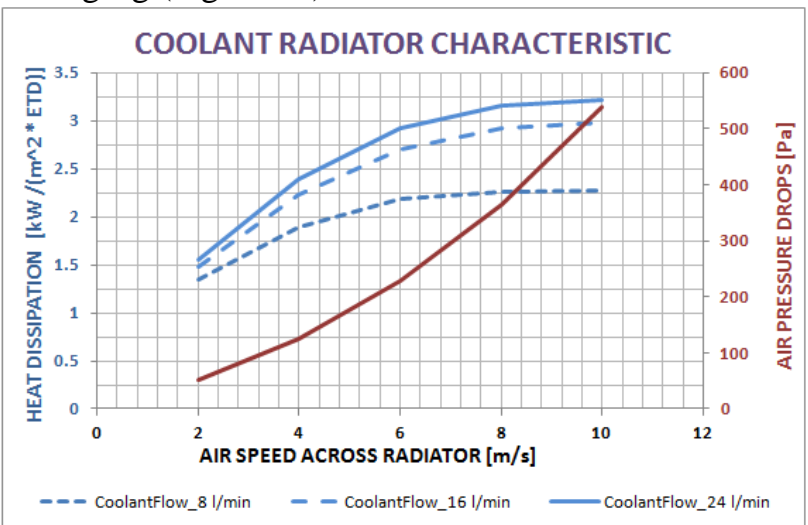

Figure 10. Coolant radiator characteristic: Heat dissipation normalized and air pressure drops

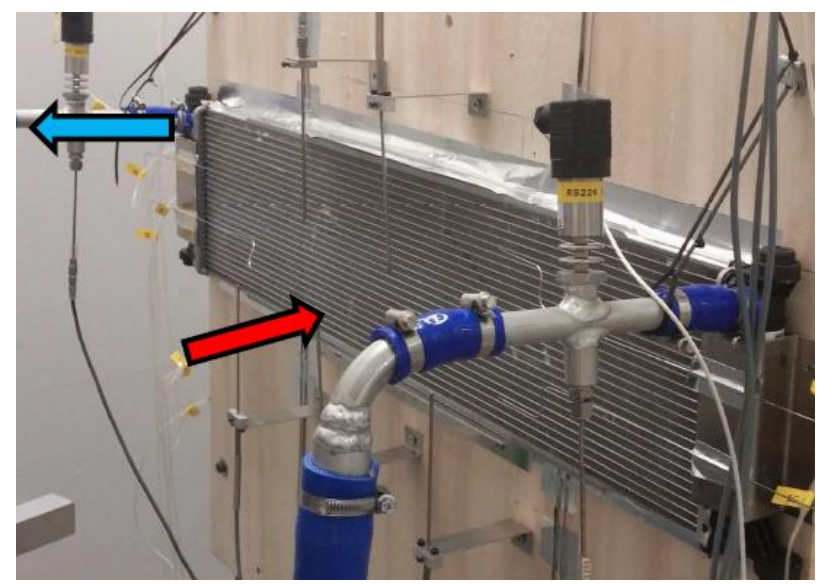

Figure 11. Radiator testing at the Dallara cooling rig

The thermal system is composed of multiple coolant radiators, complete with fans, and one chiller (plate heat exchanger).

The chiller utilizes the air conditioning refrigeration power to assist the radiators in cooling batteries and powertrain. The compressor's electrical power, 
required to activate the chiller, affects the range calculation as well.

Through one or more 4-way valves, different architectures can be studied and allow the reconfiguration of the thermal system into multiple loops in order to cool both the battery and the powertrain as a single system or as separate systems (see Figure 12).

The modularity of the thermal system model allows the analysis of different architectures to select the best solution subject to the vehicle design constraints.



Figure 12. Thermal system sub-model

The model allows the performance of weight sensitivity analysis on the range; the effect of the weight in the configurations under investigation can be considered in the choice of the thermal system architecture.

The radiator cooling efficiency is a function of the air flow across radiator, which varies with vehicle speed and fan performance.

The air flow across the radiator is calculated by considering the maximum available between the effect of the vehicle speed and the performance of the fan (Figure 13). At low vehicle speeds, the airflow due to the fan is dominant; at higher vehicle speeds the air flow is essentially a function of the vehicle speed alone. In the real world these two effects interact and provide an even higher air flow rate.

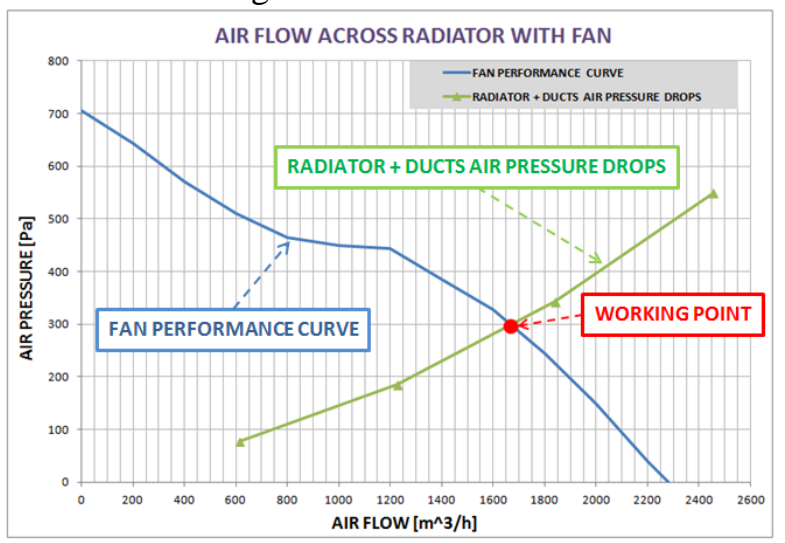

Figure 13. Fan performance curve vs radiator + duct air pressure drops
Figure 14 shows the thermal system components: chiller, radiator, battery, inverter and motor.

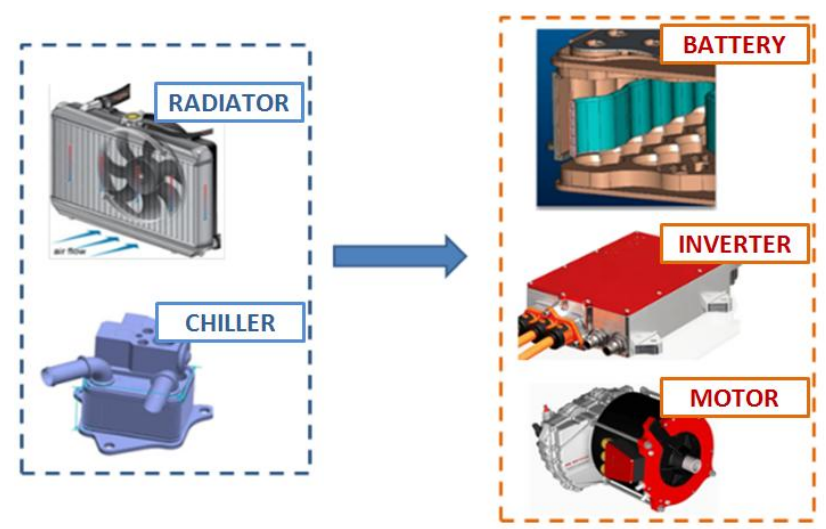

Figure 14. Thermal system components

The coolant flow rate has been calculated by considering the pump characteristic, the coolant pressure drops for each component and pipes' geometry (Figure 15). The heat exchange between pipes and the environment is also considered.
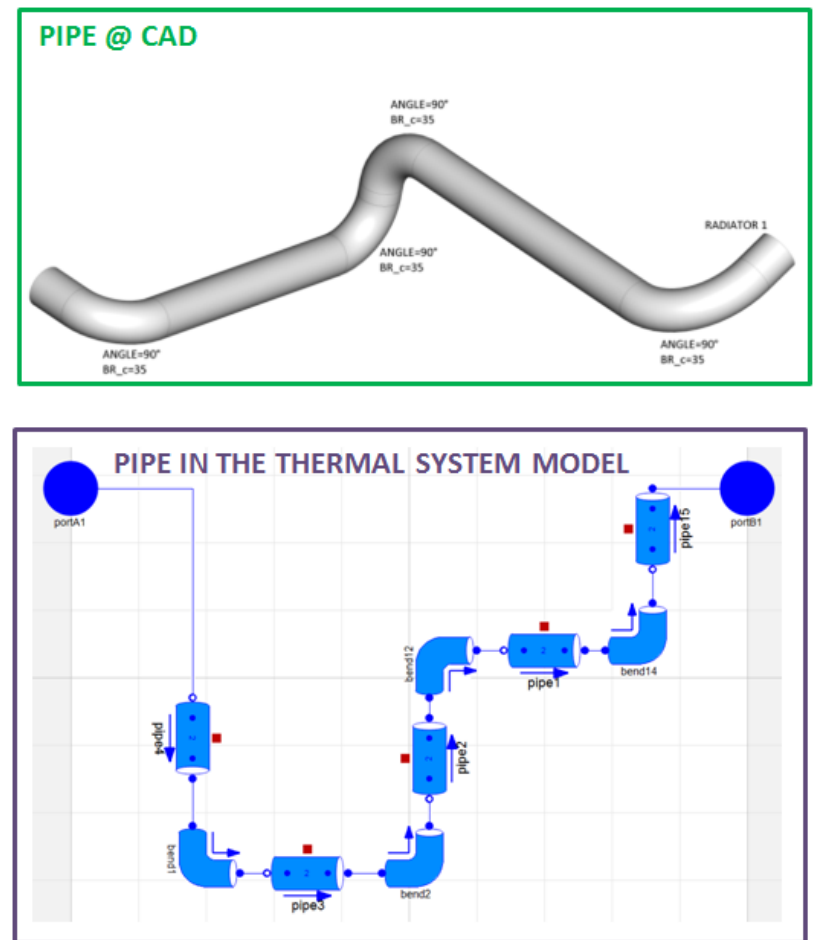

Figure 15. Pipes modeling in the thermal system, both distributed and concentrated pressure drops are considered for each pipe

The 4-way valve model, shown in Figure 16, has been developed with the Liquid Cooling Library starting from the model of the 3-way valve. 


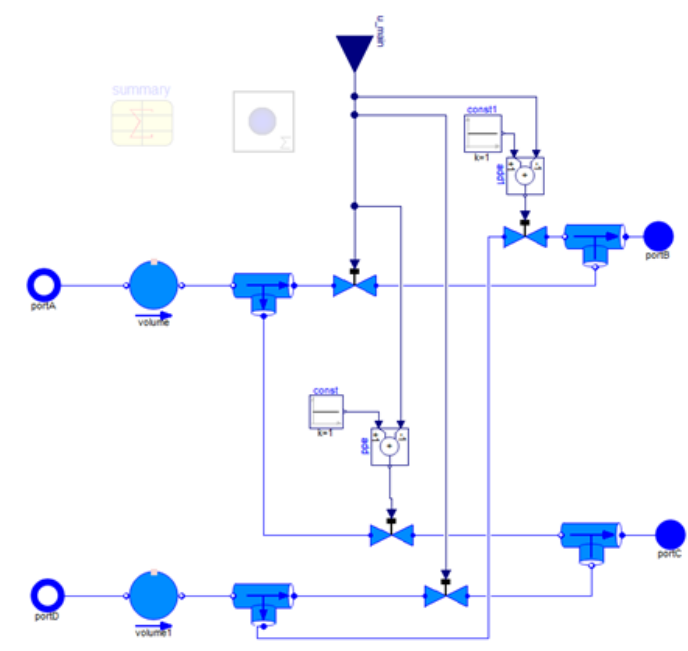

Figure 16. 4-way valve sub-model

\subsection{Control Logic Model}

The control logic analyzes the battery and powertrain coolant temperatures and continuously switches to the most efficient cooling loop configuration among those available through the thermal system model.

If the coolant temperatures reach the limits, then the control logic applies power derating.

\section{Approach}

The main purpose of designing the thermal system of an electric vehicle is to optimize the vehicle range and minimize power derating.

The chiller reduces the battery power which then makes it necessary to minimize its use to optimize the range. Moreover, as the chiller power demand to cool the battery increases, less power is available for the air conditioning of the vehicle interior, with negative implications on passenger comfort (Krüger et al, 2012).

The battery and powertrain cooling requirements vary throughout the simulation, as they depend on both the instantaneous power required to match the reference speed profile (Krüger et al, 2012), and battery and powertrain efficiency; in some conditions the powertrain requires more cooling than the battery while the opposite holds true in other conditions.

For this reason, a variable thermal system architecture is more efficient than a fixed layout in both the case of low heat rejection values to minimize the chiller use and with high heat rejection values to minimize the power derating. This variable architecture is configurable during vehicle operation in order to favor battery cooling over powertrain cooling or vice versa, depending on the instantaneous cooling requirements.

Following this approach, a variable thermal system layout has been designed to switch between three different configurations.
While the specifics of the variable system configuration are confidential, the general architecture, which shows how the coolant flow path is arranged in each configuration, is reported in Figure 17. The grey blocks represent radiators, chiller, battery and powertrain.

An outline of the three configurations is given below:

- Config $0 \rightarrow$ All components in series to cool battery and powertrain in a single system (Figure 17a). This configuration is suitable for low heat rejection requirements of both battery and powertrain with moderate ambient temperature;

- Config $1 \rightarrow$ Components in separate loops (Figure 17b) to independently cool battery and powertrain. This first "two-loops" configuration caters for high battery heat rejection and medium powertrain heat rejection requirements with medium and high ambient temperatures;

- Config $2 \rightarrow$ Components in separate loops (Figure $17 \mathrm{c})$ to cool independently the battery and powertrain. This second "two-loops" configuration caters for medium battery heat rejection and high powertrain heat rejection requirements with medium and high ambient temperatures.

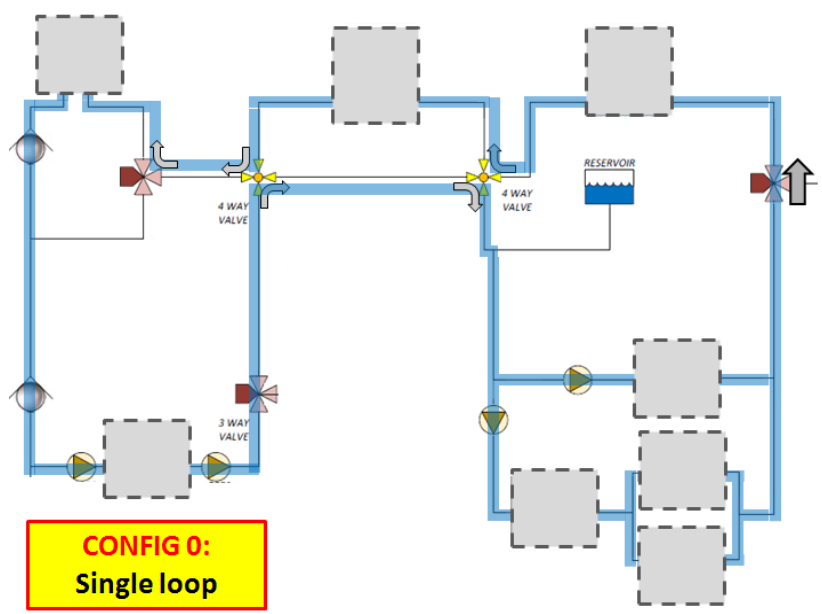

Figure 17a. Thermal system configuration 0

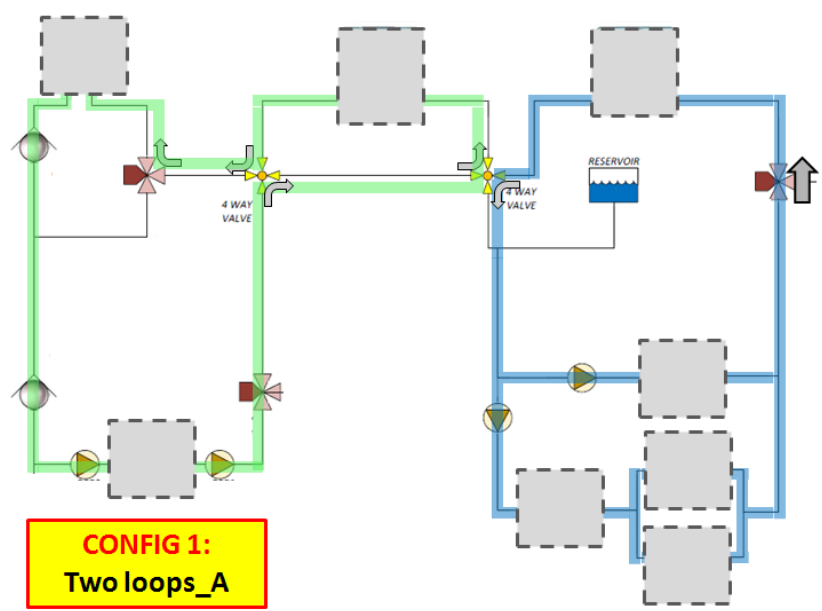

Figure 17b. Thermal system configuration 1 


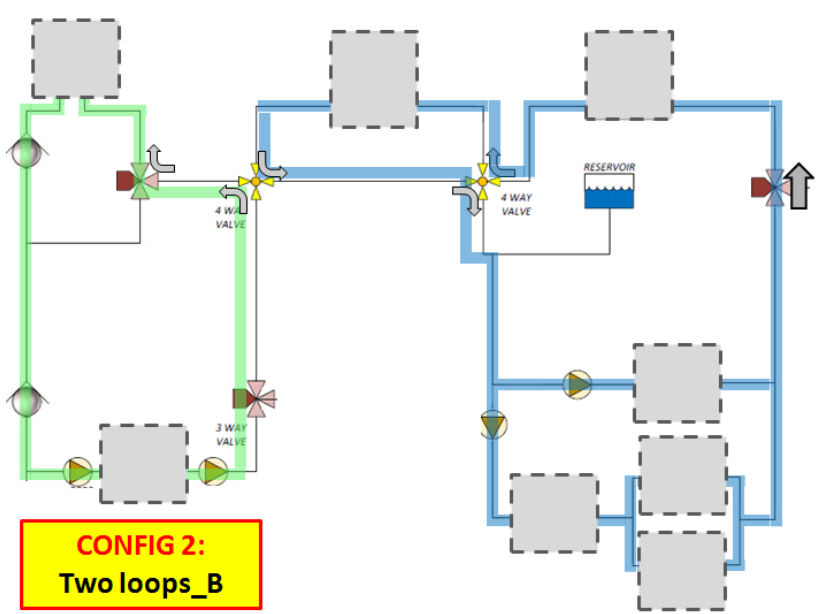

Figure 17c. Thermal system configuration 2

By monitoring the battery and powertrain coolant temperatures, the best configuration among the three choices is continuously selected by the control logic that switches from one configuration to another through two 4-way valves.

When either the battery or the powertrain coolant temperature approaches the limit values, a gradual power derating is applied.

The amount of coolant in the system plays an important role as it affects the thermal inertia and therefore the time before reaching the maximum temperature values. More coolant in the system, allows running in unstable conditions (i.e. extreme acceleration) for longer periods of time, before the control logic starts to degrade power.

This effect is shown in Figure 18, where the temperatures (considering coolant quantities of 81 and 241 in the system) are calculated for the same heat rejection profile.
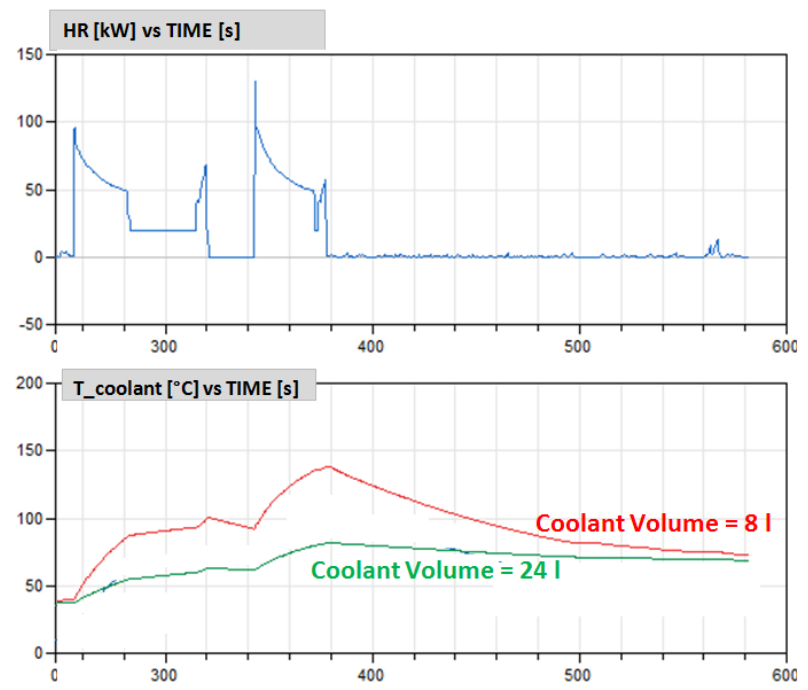

Figure 18. Coolant temperature sensitivity with coolant volume.

\section{Results}

The results reported in Figures 20-22 show the comparison between the variable thermal system architecture defined by this activity and three different fixed architectures (config 0,1,2 of Figure 17) with the same radiators and chiller of the variable thermal system. The driving cycle considered (Dimensioning Cycle) is confidential; it was developed to represent an aggressive use of the vehicle in terms of cooling requirements, Figure 19 summarizes the main input and output. A maximum available cooling power of 3 $\mathrm{kW}$ is considered for the chiller. The vehicle range is calculated with and without considering the power consumption due to the thermal components (fans, pumps and compressor). The impact of the thermal considerations of the system results in a roughly $8 \%$ decrease in vehicle range.

\begin{tabular}{|c|c|c|c|c|c|c|c|c|}
\hline \multicolumn{10}{|c|}{ DIMENSIONING CYCLE } \\
\hline CONFIG & $\begin{array}{c}\text { Tamb } \\
{\left[{ }^{\circ} \mathrm{C}\right]}\end{array}$ & $\begin{array}{c}\mathrm{T} \\
\text { coolant } \\
\text { start } \\
{\left[{ }^{\circ} \mathrm{C}\right]}\end{array}$ & $\begin{array}{c}\text { T Battery } \\
\text { cell start } \\
{\left[{ }^{\circ} \mathrm{C}\right]}\end{array}$ & $\begin{array}{c}\text { Max } \\
\text { Chiller } \\
\text { Power } \\
{[\mathrm{kW}]}\end{array}$ & $\begin{array}{c}\text { Range } \\
\text { with } \\
\text { thermal } \\
\text { loads }[\mathrm{km}]\end{array}$ & $\begin{array}{c}\text { Range } \\
\text { without } \\
\text { thermal } \\
\text { loads }[\mathrm{km}]\end{array}$ & $\begin{array}{c}\text { Compressor } \\
\text { Energy } \\
{[\mathrm{kWh}]}\end{array}$ & $\begin{array}{c}\text { TOP } \\
\text { SPEED } \\
{[\mathrm{kph}]}\end{array}$ \\
\hline $\begin{array}{c}\text { variable } \\
\text { thermal system }\end{array}$ & 33 & 42 & 42 & 3 & 188 & 205 & 0.50 & 220 \\
\hline
\end{tabular}

Figure 19. Dimensioning Cycle, input and output, variable thermal system architecture

The vehicle speed profile achievable with the variable thermal system architecture matches the Dimensioning Cycle speed profile (input) much better than the one provided by a fixed architecture, which needs more power derating (Figure 20-21). The performance gain of the variable thermal system architecture could be increased by optimizing the control logic.

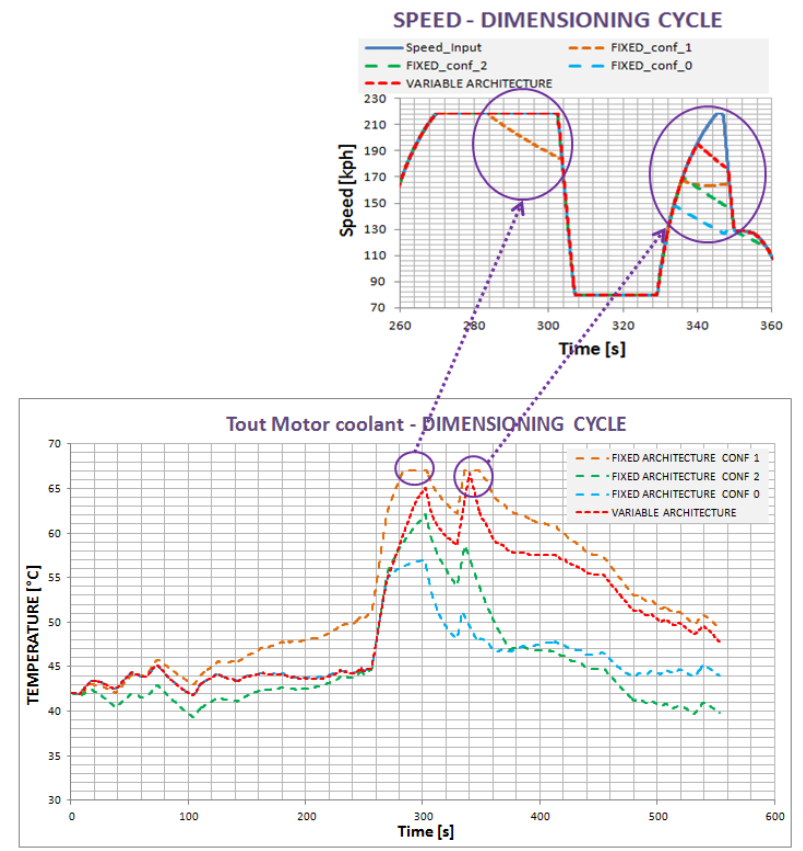

Figure 20. Dimensioning Cycle, Tout motor coolant, variable vs fixed thermal system architecture 


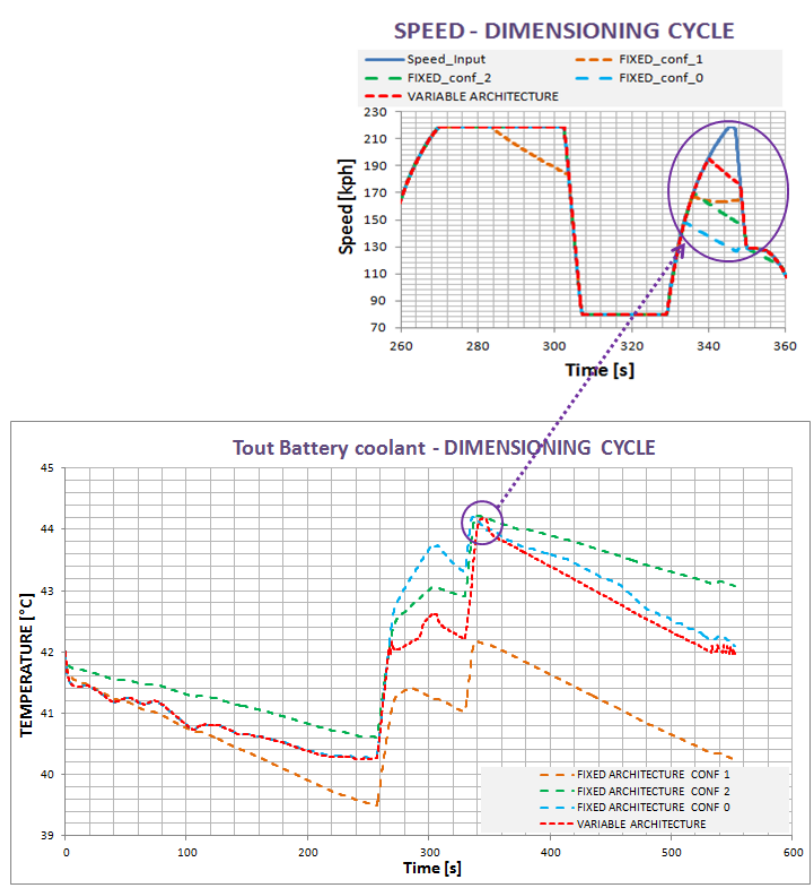

Figure 21. Dimensioning Cycle, Tout battery coolant, variable vs fixed thermal system architecture

Figure 22 shows the battery cell's temperature profile, achieved with the variable thermal system architecture in comparison with the profiles achieved with the fixed architectures.

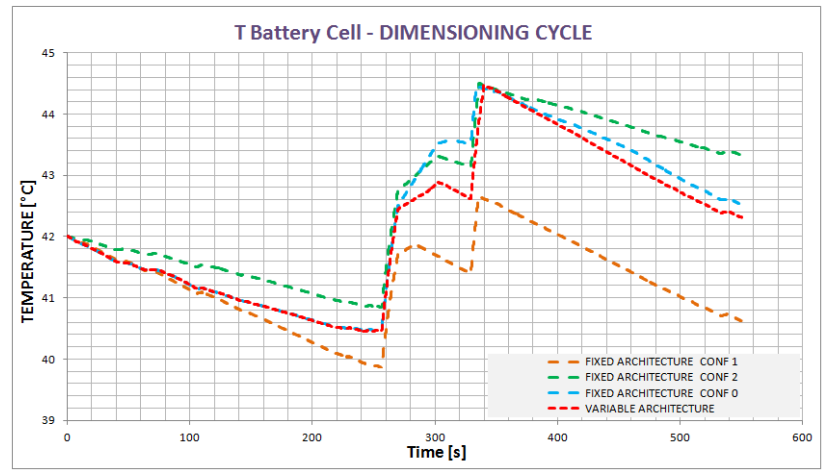

Figure 22. Dimensioning Cycle, $\mathrm{T}$ battery cell, variable vs fixed thermal system architecture

Figure 23 shows that the battery cell temperature is higher than the coolant temperature because of the thermal conductance of the cell.

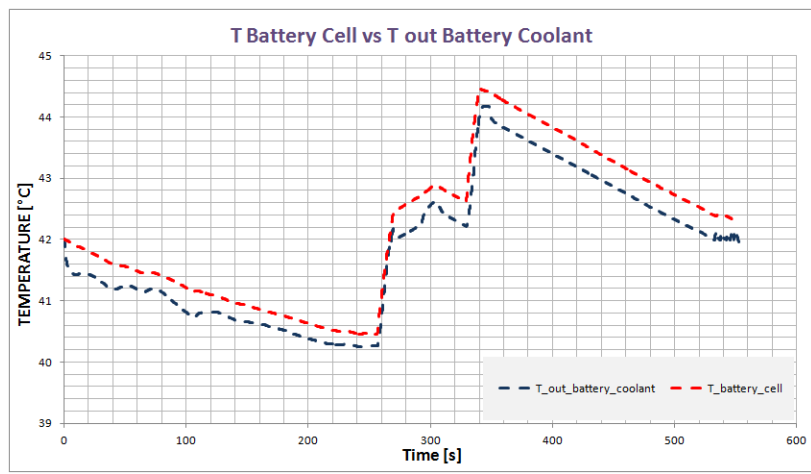

Figure 23. Dimensioning Cycle, $\mathrm{T}$ battery cell vs $\mathrm{T}$ out battery coolant, variable thermal system architecture
The thermal system configuration, managed by the control logic, changes during the simulation to best cope with the cycle requirements (Figure 24).

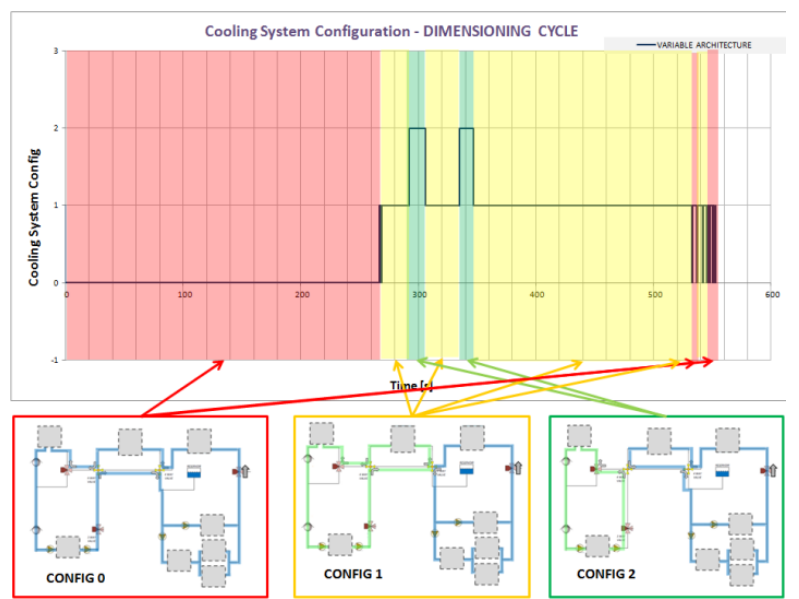

Figure 24. Dimensioning Cycle, thermal system configuration, variable thermal system architecture

The total mechanical power (front motor + rear motors) required to perform the Dimensioning Cycle is reported in Figure 25.

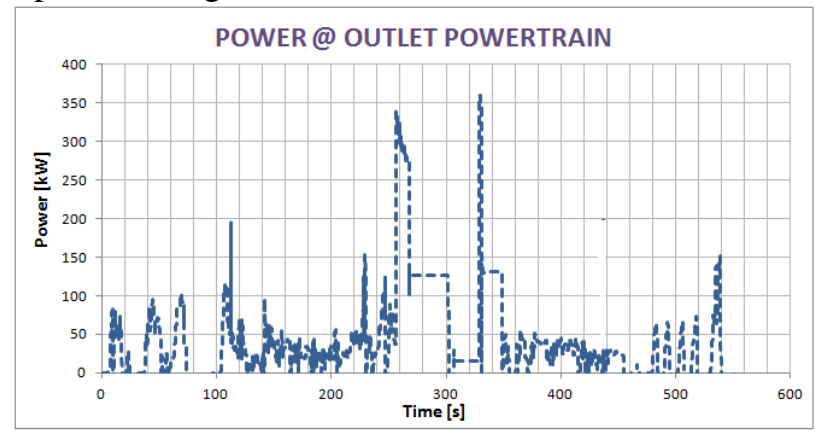

Figure 25. Dimensioning Cycle, total power (front + rear_1 + rear_2) @ outlet powertrain, variable thermal system architecture

Figure 26 shows that for low acceleration levels, the cooling demand from the powertrain is greater than the cooling demand from the battery; at high acceleration levels the opposite is true.

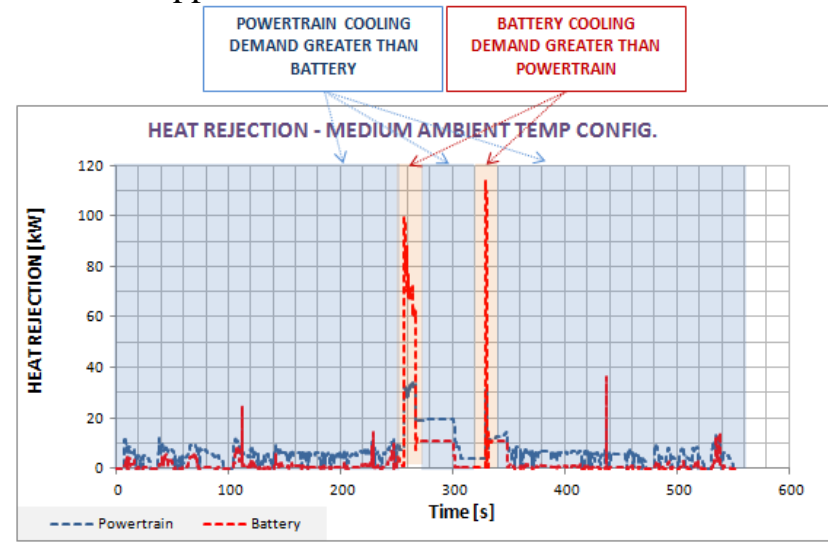

Figure 26. Dimensioning Cycle, powertrain heat rejection (front + rear_1 + rear_2) vs battery pack heat rejection, variable thermal system architecture 
Further analyses were performed on the homologation cycles US06 and NEDC where power derating is not required. All the simulations are performed considering the same SOC start $(0.95)$ and SOC end (0.15).

The homologation cycles are generally of low thermal demand, consequently the chiller is typically not necessary and a variable thermal system not required. In the real world, or considering more aggressive cycles, the advantages (energy saved) related to the introduction of a variable system architecture (with Chiller) could represent a noticeable increase of the range (up to $15 \mathrm{~km}$ ), to further minimize the power derating as reported for the dimensioning cycle.

Figure 27 summarizes the main input and output for the US06 Cycle.

\begin{tabular}{|c|c|c|c|c|c|c|}
\hline \multicolumn{7}{|c|}{ US06 CYCLE } \\
\hline \multicolumn{4}{|c|}{ INPUT } & \multicolumn{3}{|c|}{ OUTPUT } \\
\hline CONFIG & $\begin{array}{c}\text { Tamb } \\
{\left[{ }^{\circ} \mathrm{C}\right]}\end{array}$ & $\begin{array}{c}\text { Twater } \\
\text { start }\left[{ }^{\circ} \mathrm{C}\right]\end{array}$ & $\begin{array}{c}\text { Battery cell } \\
\text { temperature } \\
\text { start }\left[{ }^{\circ} \mathrm{C}\right]\end{array}$ & $\begin{array}{c}\text { Range with } \\
\text { thermal } \\
\text { loads [km] }\end{array}$ & $\begin{array}{c}\text { Range } \\
\text { without } \\
\text { thermal } \\
\text { loads [km] }\end{array}$ & $\begin{array}{l}\text { TOP } \\
\text { SPEED } \\
\text { [kph] }\end{array}$ \\
\hline variable thermal system & 33 & 42 & 42 & 380 & 382 & 130 \\
\hline
\end{tabular}

Figure 27. US06 Cycle, input and output, variable thermal system architecture

Figure 28 shows that the vehicle speed matches the US06 speed profile (input) without derating.

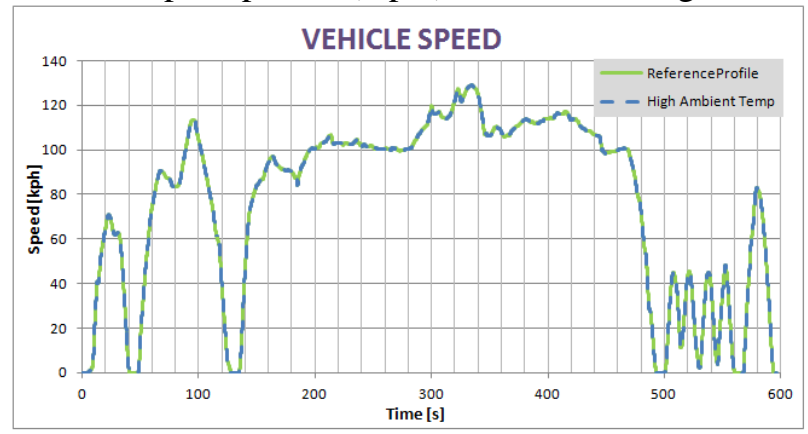

Figure 28. US06 Cycle, reference speed profile (input) vs vehicle speed, variable thermal system architecture

Figure 29 reports the motor outlet coolant temperature in the US06 cycle.

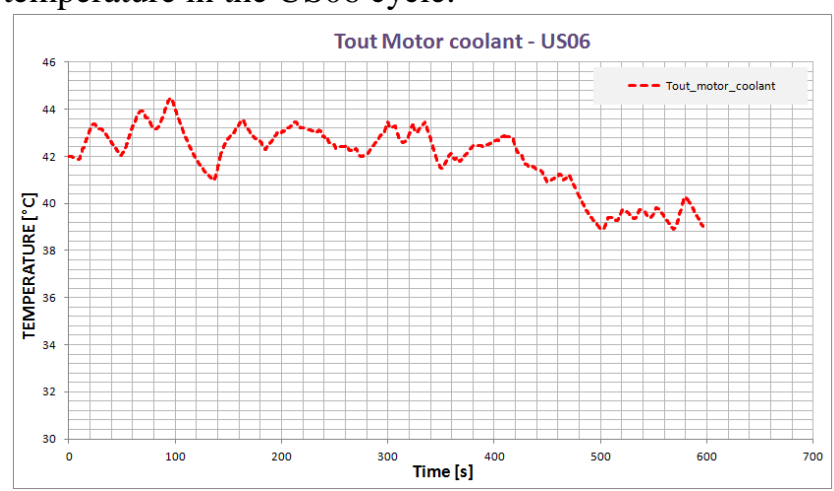

Figure 29. US06 Cycle, Tout motor coolant, variable thermal system architecture
Figure 30 reports the battery outlet coolant temperature and the battery cell temperature in the US06 cycle, the chiller is turned off.

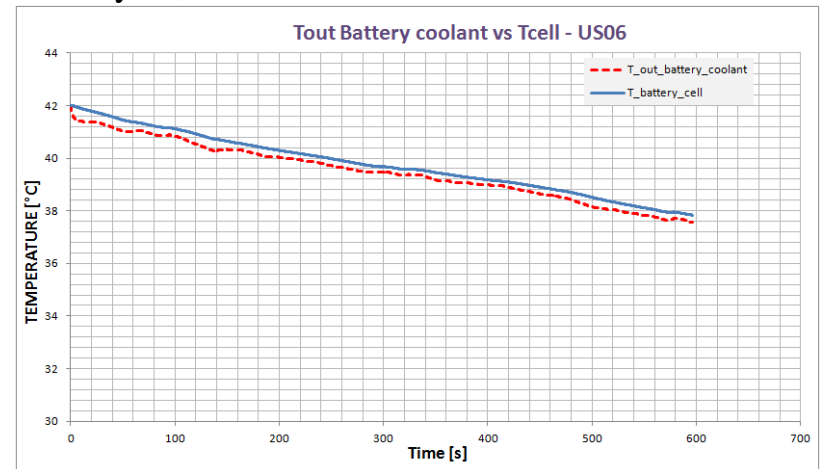

Figure 30. US06 Cycle, T battery cell vs T out battery coolant, variable thermal system architecture

Figure 31 summarizes the main input and output for the NEDC Cycle.

\begin{tabular}{|c|c|c|c|c|c|c|}
\hline \multicolumn{7}{|c|}{ NEDC CYCLE } \\
\hline \multicolumn{4}{|c|}{ INPUT } & \multicolumn{3}{|c|}{ OUTPUT } \\
\hline CONFIG & $\begin{array}{c}\text { Tamb } \\
{\left[{ }^{\circ} \mathrm{C}\right]}\end{array}$ & $\begin{array}{l}\text { Twater } \\
\text { start }\left[{ }^{\circ} \mathrm{C}\right]\end{array}$ & $\begin{array}{c}\text { Battery cell } \\
\text { temperature } \\
\text { start }\left[{ }^{\circ} \mathrm{C}\right]\end{array}$ & $\begin{array}{l}\text { Range with } \\
\text { thermal } \\
\text { loads }[\mathrm{km}]\end{array}$ & $\begin{array}{c}\text { Range } \\
\text { without } \\
\text { thermal } \\
\text { loads [km] }\end{array}$ & $\begin{array}{l}\text { TOP } \\
\text { SPEED } \\
\text { [kph] }\end{array}$ \\
\hline variable thermal system & 33 & 42 & 42 & 531 & 534 & 120 \\
\hline
\end{tabular}

Figure 31. NEDC Cycle, input and output, variable thermal system architecture

Figure 32 shows that the vehicle speed matches the NEDC speed profile (input) without derating.

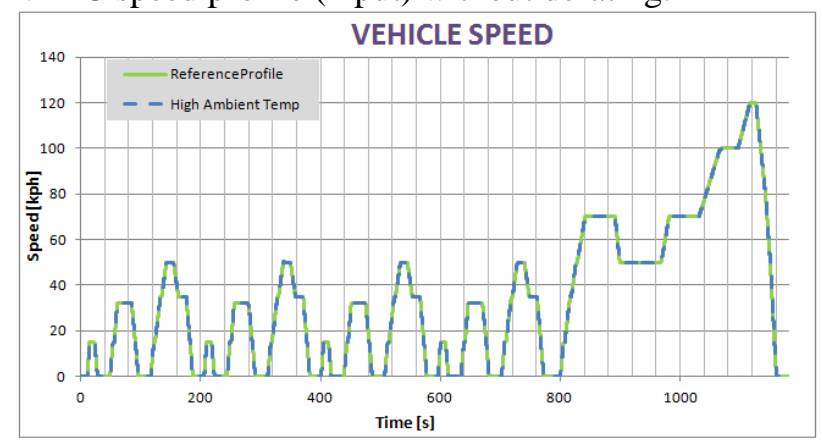

Figure 32. NEDC Cycle, reference speed profile (input) vs vehicle speed, variable thermal system architecture

Figure 33 reports the motor outlet coolant temperature in the NEDC cycle.

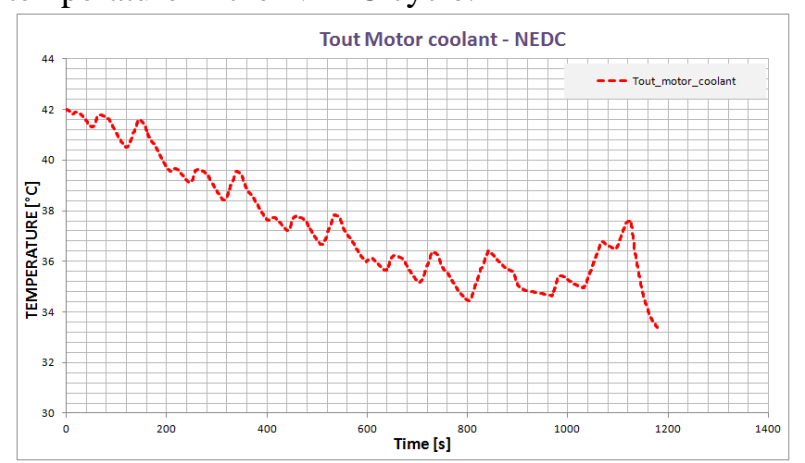

Figure 33. NEDC Cycle, Tout motor coolant, variable thermal system architecture 
Figure 34 reports the battery outlet coolant temperature and the battery cell temperature in the NEDC cycle, the chiller is turned off.

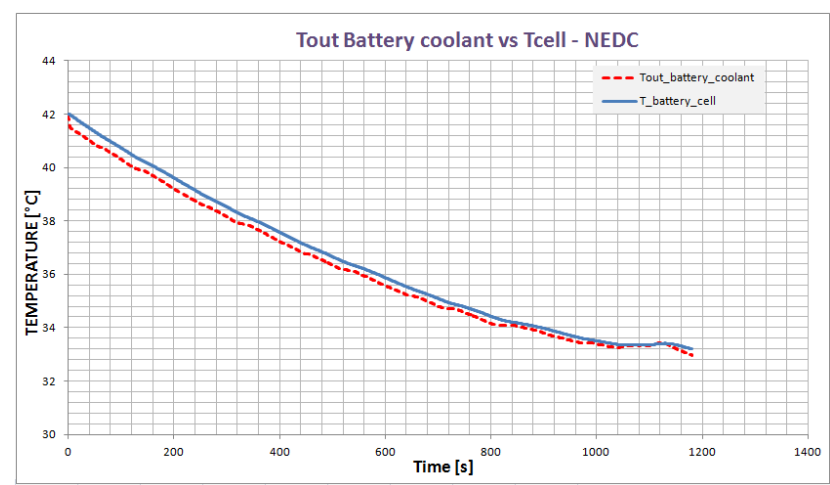

Figure 34. NEDC Cycle, $\mathrm{T}$ battery cell vs $\mathrm{T}$ out battery coolant, variable thermal system architecture

A weight sensitivity analysis has been performed on the NEDC cycle; an increase of $10 \mathrm{~kg}$ reduces the range by $2 \mathrm{~km}$.

The homologation cycles were also helpful for a first validation of the system's model, because the car manufacturers tipically declare the vehicle's range on these cycles. A systems model with the architecture and available data of a benchmark vehicle has been developed, achieving range results on US06 and NEDC cycles aligned with those declared by the benchmark vehicle constructor.

The last analysis reported (Figure 35) concerns the total electric power needed to cool the battery during the fast charge, considering a battery power supplies of $100 \mathrm{~kW}, 110 \mathrm{~kW}$ and $150 \mathrm{~kW}$; these are representative of the typical and maximum values used in the real case for the fast charge of the electric vehicles.

In all three cases analyzed the pumps and fans are kept at max rpm, the chiller power is the power in surplus at the radiator needed to keep the coolant battery temperature below its limit.

FAST CHARGE ANALYSIS @ Tamb $35^{\circ} \mathrm{C}$, T_coolant_out_bat $45^{\circ} \mathrm{C}$

\begin{tabular}{|c|c|c|c|c|c|c|c|c|c|c|}
\hline $\begin{array}{c}\text { Battery } \\
\text { Power } \\
\text { Supply } \\
{[\mathrm{kW}]}\end{array}$ & \begin{tabular}{|c|} 
Battery \\
Heat \\
Rejection \\
{$[\mathrm{kW}]$} \\
\end{tabular} & \begin{tabular}{|c|} 
Radiator \\
Heat \\
Dissip \\
{$[\mathrm{kW}]$} \\
\end{tabular} & $\begin{array}{c}\text { Coolant } \\
\text { flow } \\
{[1 / \mathrm{min}]}\end{array}$ & $\begin{array}{c}\text { COP } \\
\text { HVAC }\end{array}$ & \begin{tabular}{|c|} 
Air \\
speed \\
$@$ rad \\
{$[\mathrm{m} / \mathrm{s}]$} \\
\end{tabular} & \begin{tabular}{|c|} 
Pump \\
Electric \\
Power \\
{$[\mathrm{kW}]$}
\end{tabular} & \begin{tabular}{|c|} 
Fan \\
Electric \\
Power \\
{$[\mathrm{kW}]$} \\
\end{tabular} & \begin{tabular}{|c|} 
Chiller \\
Heat \\
Dissip \\
{$[\mathrm{kW}]$} \\
\end{tabular} & $\begin{array}{c}\text { Compres } \\
\text { Electric } \\
\text { Power } \\
{[\mathrm{kW}]} \\
\end{array}$ & $\begin{array}{c}\text { Total } \\
\text { Electric } \\
\text { Power } \\
{[\mathrm{kW}]}\end{array}$ \\
\hline 100 & \begin{tabular}{|l|}
3.8 \\
\end{tabular} & \multirow{3}{*}{8} & \multirow{3}{*}{15} & \multirow{3}{*}{1.3} & \multirow{3}{*}{5.5} & \multirow{3}{*}{0.10} & \multirow{3}{*}{0.32} & \begin{tabular}{|l|}
0 \\
\end{tabular} & \begin{tabular}{|l|}
0.0 \\
\end{tabular} & 0.4 \\
\hline 110 & & & & & & & & 0.8 & 0.6 & 1.0 \\
\hline 150 & 8.9 & & & & & & & 5.1 & 3.9 & 4.3 \\
\hline
\end{tabular}

Figure 35. Fast charge analysis, the total electric power required to cool the battery is reported in red color

\section{Conclusions and Further Developments}

The activity described in this paper was useful to evaluate the potential of the simulation model and to define the thermal system layout for a real case study.
The performance gains of a variable thermal system architecture with respect to a fixed architecture have been detailed.

The model continues to support and evolve with the case study and can be fully validated in the future with real vehicle tests, as well as being used as a starting point for future electric vehicle projects.

Ongoing work with this model to further support the case study includes the following:

- Powertrain and thermal system control logic optimization.

- Analysis of the battery heating required in low ambient temperature conditions, which constitutes another critical point in the design of Electric Vehicles (Bouvy et al, 2012).

- Analysis, supported by experimental test, of the fans and vehicle speed interaction for the air flow rate across the radiators.

- Battery model with electrochemical features development, which describes the battery physics in detail (Schmitke et al, 2015).

- Interface with the vehicle multi-body model for real time applications at Dallara Dynamic Driving Simulator.

- Air conditioning system development with effects on passenger human comfort.

- Active grill shutter model development (Batteh et al, 2014).

\section{References}

J. Batteh, S. Chandrasekar and J. Gohl. Integrated Vehicle Thermal Management in Modelica: Overview and Applications. Proceedings of 10th International Modelica Conference, pp. 409-418, 2014

C. Bouvy , P. Jeck, J. Gissing, T. Lichius, L. Ecksterin. Holistic Vehicle Simulation using Modelica - An Application on Thermal Management and Operation Strategy for Electrified Vehicles. Proceedings of 9th International Modelica Conference, pp. 263-270, 2012.

C. Bouvy, P. Jeck, S. Ginsberg, P. Jeck, B. Hartmann, S. Baltzer and L. Eckstein. Holistic Battery Pack Design. Aachen, pp. 367-380, 2012.

I. Krüger, A. Mehlhase and G. Schmitz. Energy Consumption of Battery Cooling In Hybrid Electric Vehicles. Proceedings of 14th International Refrigeration and Air Conditioning Conference, 2012.

I. Krüger, A. Mehlhase and G. Schmitz. Variable Structure Modeling for Vehicle Refrigeration Applications. Proceedings of 9th International Modelica Conference, pp. 927-934, 2012.

C. Schmitke and T. Son Dao. Developing Mathematical Models of Batteries in Modelica for Energy Storage Applications. Proceedings of 11th International Modelica Conference, pp. 469-477, 2015. $\begin{gathered}\text { Dassault Systèmes. } \\ \text { www.Dymola.com }\end{gathered}$
$\underline{\underline{n}}$ 
Modelon. Heat Exchanger Library. Version 1.4.1, 2016. www.modelon.com/products/modelicalibraries/heatexchanger-library/

Modelon. Liquid Cooling Library. Version 1.5, 2016. www.modelon.com/products/modelicalibraries/liquidcooling-library/

Modelon. Vapor Cycle Library. Version 1.3, 2016. www.modelon.com/products/modelica-libraries/vaporcycle-library/

Modelon. Vehicle Dynamics Library. Version 2.3, 2016. www.modelon.com/products/modelica-libraries/vehicledynamics-library/ 